\title{
Mathematical Creative Thinking Ability for Students Through REACT Strategies
}

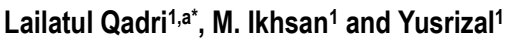 \\ 1Department of Mathematics Education, Faculty of Teachers Training and Education, Syiah Kuala University, Banda Aceh, 23111, Indonesia \\ a lailatulqadri07@yahoo.com \\ ${ }^{*}$ Corresponding Author \\ Whatsapp Number [081360954025]
}

How to Cite: Qadri,L., Ikhsan, M.,\&Yusrizal. (2019). Mathematical Creative Thinking Ability for Students Through REACT Strategies. International Journal for Educational and Vocational Studies, 1(1), 58-61. doi:

\section{ARTICLE HISTORY}

Received: 22 March 2019

Revised: 28 April 2019

Accepted: 28 May 2019

KEYWORDS

Creative Thinking

Mathematical Creative Thinking

REACT Strategies

\begin{abstract}
The ability to think creatively is important to create students who can use mathematical mindset in their daily activities, and in various sciences. The conditions at school this time show us that students still run into problems in resolve math questions which related to mathematical creative thinking ability that finally impact on the result is low for this ability. Therefore, we need strategy for mathematics learning so it can improve mathematical creative thinking ability for students. The strategy that can be applied are through Relating, Experiencing, Applying, Cooperating, dan Transferring (REACT). This research aims to know the improvement creative thinking mathematical ability for students through react strategy. The type of this research is experimental research with a quantitative approach. The populations in this study are students in class $X$ SMAN 1 Banda Aceh. The sample in this study is students in class X MIA-3 as an experimental class that gets learning with REACT's strategy, and students in class X MIA-1 as a control class that has conventional learning. The instrument of this research is the questions of pretest and post-test. The quantitative analysis using a test independent sample t-test. Based on the results of data analysis it can be concluded that improvement creative thinking mathematical ability for students by teaching with REACT's strategy is better than improvement of students' creative thinking skills by teaching conventionally.
\end{abstract}

This is an open access article under the CC-BY-SA license.

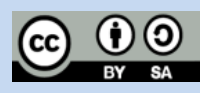

\section{INTRODUCTION}

Education is inseparable from a series of creative thinking activities, in this case one of the teaching and learning processes which is creative thinking between people who study (students) with people who teach (teachers). Learning is experienced as an internal process that complex which involves cognitive, affective, and psychomotor aspects. One of study program in education which plays an active role in improving cognitive affective and psychomotor aspects is math study program. Dimiyati dan Mudjiono (2002) said that basically the mathematics at this level of education aimed at preparing students to be able to face change in life in a world that is always develope through practice acting on the basis of creative thinking.

Creative thinking is a very important element in the development of science, technology and interaction in social activities. The development of civilization is marked by the development of knowledge which is the result of creative power and scientific communication (Mulyana, 2009).
This development includes various aspects of life including economic, social and cultural. Creative thinking also has a very important role in describes the conflicts that happen. The ability to see from many perspectives that are able to facilitate various parties and communicate them well will bridge diverse interests in their daily activity. The ability to think creatively is very necessary in the face of increasingly rapid development of knowledge. Creative thinking encourages people to be more open, so that they are more flexible, to see from various perspectives, pay attention to the slightest opportunity, try various opportunities, and never give up (Risnanosanti, 2010).

Creative individuals are capable of displaying a productive, innovative, flexible, and always optimistic work ethic, to face various possibilities that will be faced by them. For theirself, the ability to think creatively becomes the basis for responding to the response they receive. Then process it to become a product in their mind. Likewise com- 
munication skills help in giving an interpretation of the response it receives and express it in an easily understood form (Wahyudin, 2008).

Mathematical creative thinking is very important for students to develop a deep conceptual understanding of mathematics and to develop students' mathematical talents. Creative thinking is a cognitive skill that proposes various solutions to solving problems from the unknown (Aizikovitsh and Udi, 2014). Therefore, creative thinking plays an important role in determining the course of one's life and even his life in society. The latest findings cannot be separated from the existence of individual creative thinking. Creative thinking is an embodiment of the individual, a creative work as a result of someone's creative thinking that creates its own satisfaction in the personal self.

According to PISA data 2015 said that students are only able to interpret or use formulas algorithmically so it is assumed that it has not been able to develop creative thinking. Research result of Chrysmawati, Taufik, and Riyadi (2017) they found that students can only solve problems in one way or the method exemplified by the teacher. Rarely the students do it by using many methods. This is also reinforced by Nasution and Samosir (2018), and Saironi and Sukestiyarno (2017) said that the creativity of senior high school students is still low due to teacher strategies that are still not appropriate.

Effective learning strategies in mathematics learning to provide opportunities for student creativity, one of them is REACT's strategy Relating, Experiencing, Applying, Cooperating, dan Transferring). Relating is learning that begins by connecting between new concepts that are being learned with the concepts that have been mastered; Experiencing is learning that makes students learn by doing mathematical activities (doing math) through exploration, search and discovery; Applying is learning that makes students learn to apply concepts; Cooperating is learning that conditions students to learn together, share, respond to each other and think creatively with their fellow friends; while what is meant Transferring is learning that encourages students to learn by using the knowledge they have learned in class based on creative thinking (Crawford, 2001).

Learning with REACT's strategy is a bridge in the process of learning mathematics which aims to strive to increase the ability to think creatively. This is supported by the research result of Dewi, Aminah, and Sukarmin (2015) shows that the REACT's strategy is able to improve the ability to think creatively.

According to the results of observations of researchers with mathematics study teachers at SMAN 1 Banda Aceh, show that students' ability and hard work and creative creative thinking are needed, so that the learning will be increase. Conventional learning applied by teachers is still not optimal for improving students' creative mathematical thinking skills. Teachers need to implement learning strategies that can improve students' creative thinking skills in mathematics. REACT's strategy is one alternative to change things to be more effective. Based on the background described, This reserch aims to determine the improvement of mathematical creative thinking skills of students who get learning with REACT's strategy and students who get conventional learning.

\section{METHOD}

This research is an experimental research with a quantitative approach. The experimental design used in this study is Pretest-posttets Control Group Design. This design was chosen because the study sample involved two sample groups namely the experimental group and the control group.

The population in this study were class $\mathrm{X}$ students SMAN 1 Banda Aceh. This school was chosen as the population in this study because the school is one of the schools that is open to the latest learning innovations making it easier for researchers to conduct research. Sampling in research is done by random sampling of all class X students. One class was chosen as the experimental class and the next class as the control class. The experimental class is the X MIA-3 class whose learning is done with the REACT's strategy while class X MIA-1 as a learning control class is done conventionally.

This study uses an instrument in the form of pretest and posttest creative thinking skills carried out on material similarities and linear inequalities. Pretest is given before learning is done, whereas posttes are given after the entire meeting ends. Indicators of mathematical creative thinking skills that become benchmarks are flexibility, fluency, authenticity, and elaboration.

The research hypothesis is that the improvement in mathematical creative thinking skills of students who get learning with REACT strategies is better than students who get conventional learning.

To test the hypothesis, a statistical analysis of the test was carried out by comparing the average test score using the t-test, is Independent sample t-test. This test can be used as a measurement tool to find out the mathematical creative thinking skills taught using the REACT's strategy are better than students taught with conventional learning.

\section{RESULTS AND DISCUSSION}

Data obtained from the results of the study are in the form of quantitative data which is a data of mathematical creative thinking abilities of experimental class students consisting of 33 students and a control class consisting of 32 students. The statistical test used to test the difference in the average of the two samples is the t-test. The difference test of the average $\mathrm{N}$-gain score is done to prove the improvement of mathematical creative thinking abilities of students who get learning with REACT's strategy better than students who get conventional learning. The testing criteria at a significant level $\alpha=0.05$ are accept $\mathrm{H} 0$ if sig. $\geq$ 0.05. The research hypothesis for $\mathrm{HO}$ is that there is no 
difference in the increase in mathematical creative thinking abilities of students who have learned through REACT's strategy with mathematical thinking skills of students who obtain conventional learning, while $\mathrm{H} 1$ is an increase in mathematical creative thinking skills of students who have learned through REACT's strategy better mathematical creative thinking skills of students who obtain conventional learning.

In summary the analysis of the test results of the average difference in data $\mathrm{N}$-gain mathematical creative thinking skills of students obtained 0,000 which means less than $\alpha=0.05$. The $\mathrm{t}$-count $=3.907 \geq 1 ., 998(\mathrm{t}$ table $=1.998)$, shows that the increase in mathematical creative thinking skills of students who get REACT's strategy learning is better than students who get conventional learning.

The findings are in line with the results of Sapto, Suyitno, and Susilo (2015) 's research concluding that an increase in mathematical creative thinking skills of students who obtain REACT's strategy is higher than students who obtain conventional learning.

Improving the ability of students to think creatively mathematically better in the experimental class shows that students can understand well the concepts given through learning the REACT's strategy. Other than that, this learning strategy requires students to do more problem solving activities found in the Student Worksheet (LKPD) facilitated by the teacher. Student activities in REACT's strategy learning also increased during the learning process which lasted five meetings. Learning in the first and second meetings, students are still not familiar with the application of the REACT's strategy so that student activities are still not active yet. Students listen more to the direction and explanation from the teacher, but have not dared to carry out the investigation independently so the teacher is still dominant in conducting guidance. The results of this study are also in line with the results of the research of Jelatu, Sariyasa, \& Ardana (2018) which suggested that the activities of students in the first meeting were still not conducive because students were still awkward because they were not familiar with the REACT's strategy.

The next meeting students have begun to be active in the learning process because students are familiar with the REACT's strategy. Teachers only provide guidance when students experience difficulties, but students are more dominant in conducting investigations to find concepts about equations and linear inequalities of two variables. Students are independent in using and filling out the Student Worksheet. LKPD that is discussed by students in their groups makes students interact with each other so that students together build their knowledge and deepen their understanding through the LKPD. This is in accordance with the results of research by Ritonga (2017) which revealed that student learning activities with REACT strategies were better than student learning activities in the control class and the attitudes of students in the experimental class were far more positive than those in the control class.
The improvement of students' mathematical thinking skills through learning through the implementation of the REACT's strategy is better than the mathematical thinking ability of students who have learned from the REACT's strategy due to the atmosphere and learning process that involves students to be more active. Karsli and Yigit (2016) suggest that in the REACT strategy students are actively involved in the learning process so students are able to solve the math problems given. In addition, the results of research by Dewi, Aminah, \& Sukarnin (2015) concluded that the application of REACT strategy resulted in better mathematical creative thinking skills because all students were actively involved in the learning process and students emphasized the discovery of concepts by finding themselves or with teacher guidance so they could remember the concept for a long time and the ability to think mathematically increases.

\section{CONCLUSION}

Based on the analysis and discussion that has been described, it can be concluded that the increase in mathematical thinking skills of students who get learning with REACT's strategy is better than increasing the mathematical thinking skills of students who get conventional learning.

\section{REFERENCES}

Aizikovitsh, Udi, E. 2014. The Extent of Mathematical Creativity and Aesthetics in Solving Problems among Students Attending the Mathematically talented Youth Program. Creative Education. 5: 228 - 241.

Chrysmawati, L., Taufik, A., Riyadi, M. 2017. Penerapan Model Discovery Learning Berbantuan Alat Peraga Pentas Trigonometri untuk Meningkatkan Kemampuan Berpikir Kreatif Matematis Siswa. Seminar Nasional Pendidikan Matematika 2017, Tema "Inovasi Pembelajaran Berbasis Mulitmedia".

Crowford, M. T. 2001. Teaching and Learning. Rescarch, Rationale, and Techniques for Inproving Motivation and Achievement in Mathematics and science, Waco, Texas, CCI Publising. pp. 3.

Dewi, N. A. K., Aminah, N. S., dan Sukarmin. 2015. Pengembangan modul fisika berbasis relating, experiencing, applying, cooperating, and transferring (REACT) untuk Meningkatkan Kecerdasan Majemuk dan Kreativitas Siwa. Jurnal Inkuri, 4(2): 47-56.

Dimyati, Mudjiono. 2002. Belajar dan Pembelajaran. Jakarta: Rineka Cipta.

Jelatu, S., Sariyasa, Ardana, M. I. 2018. Effect of GeoGebra-Aided REACT Strategy on Understanding of Geometry Concepts. International Journal of Instruction, 11(4): 325-336.

Karsli, F., Yigit, M. 2016. 12 ${ }^{\text {th }}$ Grade students' views about an Alkanes Workshee Based on the REACT Strategy. Necatibey Faculty of Education Electronic Journal of Science and Mathematics Education, 10(1): 472-499.

Komalasari. K. 2010. Pembelajaran Kontekstual-Konsep dan Aplikasi. Bandung: PT. Refika Aditama.

Mulyana, T. 2009. Pembelajaran Analitik Sintetik untuk Meningkatkan Kemampuan Berpikir Kritis dan Kreatif Matematis Siswa SMA. Jurnal Educationist. 3: 1907-8838.

Nasution, I. S., Samosir, B. S. 2018. Model Pembelajaran Connecting, Organizing, Reflecting, dan Extending (CORE) Untuk Meningkatkan Kreativitas Siswa di SMK Muhammadiyah 13 Sibolga. Jurnal Penelitian Tindakan Kelas dan Pengembangan Pembelajaran). 1(3): 213- 221. 
Risnanosanti. 2010. Kemampuan Berpikir Kreatif Matematis dan Self Efficacy Terhadap Matematika Siswa Sekolah Menengah Atas (SMA) dalam pembelajaran Inkuiri. Bandung: UPI.

Ritonga, S. M. 2017. Peningkatan Kemampuan Pemecahan Masalah Dan Komunikasi Matematik Siswa SMP Negeri 28 Medan Melalui Pembelajaran Inkuiri Dengan Strategi REACT. AXIOM. 4(1): 1-13.

Saironi, M., Sukestiyarno, YL. 2017. Kemampuan Berpikir Kreatif Matematis Siswa dan Pembentukan Karakter Rasa Ingin Tahu Siswa pada Pembelajaran Open Ended Berbasis Etnomatematika. Unnes Journal of Mathematics Education Research. 6(1): 76-88.

Sapto, A. D., Suyitno, H., Susilo, B. E. 2015. Keefektifan Pembelajaran Strategi REACT dengan Model SSCS Terhadap Kemampuan Komunikasi Matematika dan Percaya Diri Siswa Kelas VIII. Unnes Journal of Mathematics Education, 4(3): 223-229. 